\title{
Ochrona sądowa w postępowaniach dyscyplinarnych lekarzy. Analiza orzeczeń kasacyjnych Sądu Najwyższego
}

\section{Zagadnienia wstępne}

М polskiej procedurze karnej instytucja kasacji jest nadzwyczajnym środkiem $\bigvee$ prawnym, służącym do wywołania kontroli i wzruszenia prawomocnego orzeczenia sądowego kończącego postępowanie. Jako nadzwyczajny środek zaskarżenia kasacja w postępowaniu karnym służy kontroli orzeczeń prawomocnych - ze względu na uchybienia, które nie zostały dostrzeżone w toku kontroli instancyjnej, lub takie, które dotyczą orzeczenia zapadłego przed sądem drugiej instancji. W dwuinstancyjnym postępowaniu karnym kasacja pełni zatem rolę swoistego „wentyla bezpieczeństwa”, uzupełnia system dwuinstancyjnej kontroli sądowej, stwarzając możliwość eliminowania najpoważniejszych błędów wymiaru sprawiedliwości zawartych w prawomocnych orzeczeniach ${ }^{1}$. $\mathrm{W}$ tym aspekcie warto przyjrzeć się czego dotyczyły kasacje w postępowaniu dyscyplinarnym lekarzy w latach 2011-2016:

- Nie zachowanie należytej staranności;

- Doprowadzenie wbrew woli pacjentów do innych czynności seksualnych;

- Niezachowanie ostrożności w formułowaniu opinii o innym lekarzu;

- Brak uprawnień do wykonywania określonych czynności;

\footnotetext{
* Dr NAUK PRAWNych, LEK. MED. IWONA WrZeŚNiewSKA-WAL - p.o. kierownik Zakładu Ekonomiki, Prawa i Zarządzania Szkoły Zdrowia Publicznego w Centrum Medycznego Kształcenia Podyplomowego w Warszawie.

1 Wyrok Trybunału Konstytucyjnego z dnia 17 maja 2004 r., sygn. akt SK 32/03, OTK ZU nr 5/A/2004, poz. 44 T. Grzegorczyk, [w:] T. Grzegorczyk, J. Tylman, Polskie postępowanie karne, wyd. 6, Warszawa 2007, s. 909
} 
- Nieprawidłowe prowadzenie i nie udostępnianie dokumentacji medyczne;

- Niepłacenie składek.

Wyraźnie widać, że zakres orzecznictwa sądów lekarskich, które są poddane kontroli kasacyjnej dotyczy fundamentalnych dla zawodu lekarza zagadnień.

W doktrynie i w orzecznictwie podkreśla się, że w przypadku sądownictwa dyscyplinarnego kasacja spełnia szczególną rolę, gdyż postępowanie to ma charakter represyjny ${ }^{2}$. Problematyka kasacji w postępowaniach dyscyplinarnych była wielokrotnie poruszana w judykaturze Trybunału Konstytucyjnego. Pogląd, zgodnie $\mathrm{z}$ którym prawo do sądu powinno być zagwarantowane $\mathrm{w}$ ramach każdego postępowania dyscyplinarnego występuje w orzecznictwie Trybunału Konstytucyjnego już od lat $90^{3}$. Trybunał Konstytucyjny wskazywał, że prawo do sądu winno być realizowane przez możliwości weryfikowania przez sąd prawidłowości orzeczenia każdego organu pozasądowego ${ }^{4}$. Linia ta utrzymuje się w późniejszym orzecznictwie, gdzie Trybunał Konstytucyjny zwraca uwagę na konieczność stosowania, także w postępowaniach dyscyplinarnych, gwarancji ustanowionych w rozdziale II Konstytucji, odnoszących się do wszelkich postępowań represyjnych, tzn. postępowań, których celem jest poddanie obywatela jakiejś formie ukarania lub jakiejś sankcji ${ }^{5}$. Ustawa o izbach lekarskich w art. 83 ust. $1^{6}$ przewiduje szereg kar dyscyplinarnych m.in. upomnienie, naganę, karę pieniężną, ograniczenie zakresu czynności wykonywania zawodu lekarza, zakaz pełnienia funkcji kierowniczych w jednostkach ochrony zdrowia oraz karę ograniczenia a nawet pozbawianie prawa wykonywania zawodu.

W każdej sprawie dyscyplinarnej, która była przedmiotem rozstrzygania $\mathrm{w}$ pozasądowym postępowaniu dyscyplinarnym ustawodawca powinien zapewnić prawo do wszczęcia sądowej kontroli postępowania dyscyplinarnego i zapadłego w jego wyniku orzeczenia ${ }^{7}$. Podobne stanowisko zajął Sąd Najwyższy uznając, że kwestia legalności i zasadności procedur dyscyplinarnych prowadzących do pozbawienia lub zawieszenia prawa wykonywania zawodu jest sprawą, w której należy rozważyć konstytucyjne prawo do sprawiedliwego i jawnego jej

${ }^{2}$ Wyrok Trybunału Konstytucyjnego z dnia 25 czerwca 2012 r. sygn. akt K 9/10 (Dz. U. 2012, poz. 760$)$

3 Taki wniosek wyprowadził Trybunał Konstytucyjny z zasady demokratycznego państwa prawnego: Orzeczenie Trybunału Konstytucyjnego z dnia 1 marca 1994 r., sygn. akt. U 7/93, Legalis Numer 10199 oraz Orzeczenie Trybunału Konstytucyjnego z dnia 26 kwietnia 1995 r., sygn. akt. K 11/94 (OTK 1995, poz. 12), Legalis Numer 10252

${ }_{4}^{4}$ Orzeczenie Trybunału Konstytucyjnego z dnia 8 grudnia 1998 r., sygn. akt. K 41/97OTK 1998 $\mathrm{nr}$ 7, poz. 117, Legalis Numer 10465

${ }^{5}$ Wyrok Trybunału Konstytucyjnego z dnia 4 marca 2008 r. sygn. akt SK 3/07 (Dz.U. 2008 nr 41, poz. 251)

${ }^{6}$ Ustawa z dnia 2 grudnia 2009 r. o izbach lekarskich (Dz. U. 2009 nr 219 poz. 1708 z późn. zm.)

7 Wyrok Trybunału Konstytucyjnego z dnia 16 marca 1999 r., sygn.. akt SK 19/98, OTK 1999 nr 3, poz. 36 
rozpatrzenia bez nieuzasadnionej zwłoki przez właściwy, niezależny, bezstronny i niezawisły sąd (art. 8 i 45 ust. 1 Konstytucji Rzeczypospolitej Polskiej) ${ }^{8}$.

Kasacja od wyroku sądu dyscyplinarnego nie powinna być utożsamiana $\mathrm{z}$ kasacją $\mathrm{w}$ postępowaniu karnym. Kasacja w postępowaniu dyscyplinarnym jest instrumentem umożliwiającym uruchomienie kontroli orzeczenia organu dyscyplinarnego przez sąd, podczas gdy w postępowaniu karnym rozstrzyganie sprawy odbywa się od początku do końca przez sądy państwowe. Powołując się na orzecznictwo Trybunału Konstytucyjnego, Prokurator Generalny uznał, że przyjęty model sądowej kontroli postępowania dyscyplinarnego, w którym sąd posiada uprawnienie do kontroli prawidłowości tego postępowania, a w konsekwencji do uchylenia orzeczenia sądu dyscyplinarnego, gwarantuje wystarczający standard ochrony konstytucyjnej osób, które są członkami korporacji zawodowej ${ }^{9}$. W przypadku sądownictwa dyscyplinarnego kasacja spełnia szczególną rolę. Zagwarantowanie przez ustawodawcę osobom wykonującym zawód zaufania publicznego prawo do sądu stanowi ważny element nadzoru państwa nad działalnością samorządów zawodowych. Autorka artykułu podjęła próbę analizy orzeczeń kasacyjnych Sądu Najwyższego dotyczących postępowania dyscyplinarnego lekarzy w celu oceny trwałości i jakości orzecznictwa sądów lekarskich. Tym samym ocenie podlegać będzie efektywność ochrony sądowej tych postępowań.

\section{Podmioty uprawnione do wnoszenia kasacji w postępowaniu dyscyplinarnym lekarzy}

Przepis art. 95 ustawy o izbach lekarskich stanowi, że kasacja przysługuje od prawomocnego orzeczenia Naczelnego Sądu Lekarskiego stronom, ministrowi zdrowia i Prezesowi Naczelnej Rady Lekarskiej. Już na początku warto podkreślić, że w stosunku do poprzednich regulacji dotyczących rewizji nadzwyczajnej przyznanie stronom prawa do zaskarżania w trybie kasacji prawomocnych orzeczeń kończących postępowanie w sprawie zasługuje na pozytywną ocenę, było to zresztą od dawna postulowane $\mathrm{z}$ doktrynie ${ }^{10}$. Jest to zerwanie $\mathrm{z}$ występująca w warunkach rewizji nadzwyczajnej wyłącznością kompetencji organów urzędowych. Niewątpliwie nadało to kasacji charakter środka procesowego pozwalającego stronom na kształtowanie ich własnej sytuacji procesowej ${ }^{11}$.

\footnotetext{
8 Wyrok Sądu Najwyższego z dnia 4 kwietnia 1999 r., sygn. akt I PKN 648/98, LEX nr 37708

9 Wyrok Trybunału Konstytucyjnego z dnia 25 czerwca 2012, sygn. akt K 9/10, (Dz.U. 2012, poz. 760)

10 E. Zielińska, Odpowiedzialność zawodowa lekarza i jej stosunek do odpowiedzialności karnej, Warszawa 2001, s. 322

11 M. Rogacka-Rzewnicka: Kasacja w polskim procesie karnym, Warszawa 2001, s. 107-108
} 
Wśród podmiotów uprawnionych do wniesienia kasacji jest minister zdrowia i Prezes Naczelnej Rady Lekarskiej, nie ma natomiast Rzecznika Praw Obywatelskich. W postępowaniu karnym zgodnie z art. 521 k.p.k. Rzecznik Praw Obywatelskich jest podmiotem uprawnionym do wnoszenia kasacji nadzwyczajnej, która ma szerszy zakres niż przysługująca stronom z art. 519 k.p.k. W doktrynie podkreśla się, że podmioty kwalifikowane uprawnione do wniesienia tego typu kasacji nie kierują się swoimi prawami lub interesami, wnoszą kasację nadzwyczajną z urzędu, niekiedy zainicjowane przez prośby stron ${ }^{12}$. Niewątpliwie rzecznik Praw Obywatelskich stoi na straży wolności i praw człowieka i obywatela ${ }^{13}$. Jednak przepisy dotyczące kasacji nadzwyczajnej, zgodnie z utrwalonym już stanowiskiem doktryny i orzecznictwa, nie mają zastosowania w postępowaniach dyscyplinarnych wobec zawodów prawniczych ${ }^{14}$. Sąd Najwyższy stwierdził, że: „Nie do przyjęcia jest teza, że obowiązujący model postępowania dyscyplinarnego w stosunku do adwokatów przewiduje dwa odrębne tryby postępowania kasacyjnego, zakotwiczone $\mathrm{w}$ dwóch różnych aktach normatywnych, różne co do przedmiotu zaskarżenia i podmiotów uprawnionych do wniesienia kasacji, z których jeden tryb jest wyraźnie skonstruowany dla potrzeb tego postępowania i umieszczony w ustawie o charakterze ustrojowym dla korporacji adwokackiej, a drugi miałby wynikać z ogólnego odesłania do innego aktu normatywnego"15. Tym samym przepisy dotyczące kasacji nadzwyczajnej nie będą miały również zastosowania w przedmiocie odpowiedzialności zawodowej lekarzy. Zawody te posiadają ten sam model kontroli orzeczeń drugoinstancyjnych zapadłych $\mathrm{w}$ postępowaniu dyscyplinarnym ${ }^{16}$. Pomimo to warto zwrócić uwagę, że w przypadku zawodów prawniczych Rzecznik Praw Obywatelskich posiada ustawowe uprawnienia do wniesienia kasacji w sprawach: adwokatów ${ }^{17}$ oraz radców prawnych $^{18}$. W porównaniu $\mathrm{z}$ tymi regulacjami w tej kwestii ustawa o izbach lekarskich zawęża krąg podmiotów uprawnionych do wniesienia kasacji.

Ponadto inaczej niż w postępowaniu karnym ustawa o izbach lekarskich rozwiązała kwestię wnoszenia kasacji. Przypomnijmy, że zgodnie z art. $525 \S$ 1 i 2 k.p.k. strona wnosi kasację do Sądu Najwyższego za pośrednictwem sądu odwoławczego. W wypadku podmiotów szczególnych uprawnionych do wno-

12 J. Skorupka [red] Kodeks postępowania karnego - komentarz, Warszawa 2016, s. 1211

13 Art. 208 Konstytucji Rzeczpospolitej Polskiej z 2 kwietnia 1997 r. ( Dz. U. Nr 78, poz. 483)

${ }_{14}$ Orzeczenia Sądu Najwyższego wobec adwokatów: SDI 30/06, SDI 5/07, SDI 1/08, SDI 5/08, SDI 35/10, SDI 36/10 [w:] P. Czarnecki, Postępowanie dyscyplinarne wobec osób wykonujących prawnicze zawody zaufania publicznego, Warszawa 2013, s. 373

${ }_{15}$ Postanowienie SN z dnia 11 lutego 2008 sygn. akt SDI 1/08, OSNKW 2008 nr 4, poz. 30

${ }^{16}$ P. Czarnecki, Postępowanie dyscyplinarne wobec osób wykonujących prawnicze zawody zaufania publicznego, Warszawa 2013, s. 370

17 Art. 91a ustawy z dnia 26 maja 1982 r. Prawa o adwokaturze (Dz. U. z 2009 r. Nr 16, poz. 124 z późn. zm)

${ }_{18}$ Art. 622 ustawy z dnia 6 lipca 1982 r. o radcach prawnych (Dz. U. Nr 9, poz. 145 z późn. zm.) 
szenia kasacji: Ministra Sprawiedliwości - Prokuratora Generalnego, a także Rzecznika Praw Obywatelskich i w pewnym zakresie Rzecznika Praw Dziecka kasację wnosi się bezpośrednio do Sądu Najwyższego. Ustawa o izbach lekarskich w art. 97 stanowi, że strony, minister właściwy do spraw zdrowia i Prezes Naczelnej Rady Lekarskiej wnoszą kasację do Sądu Najwyższego za pośrednictwem Naczelnego Sądu Lekarskiego. Ponadto kasacja wnoszona przez stronę powinna być sporządzona i podpisana przez obrońcę będącego adwokatem albo radcą prawnym albo pełnomocnika będącego adwokatem albo radcą prawnym. Nie należy zapominać, że w postępowaniu sądowym w odpowiedzialności zawodowej lekarzy stroną jest również Rzecznik Odpowiedzialności Zawodowej. W praktyce sądów lekarskich najczęściej kasację do Sądu Najwyższego kierują za pośrednictwem swoich pełnomocników strony: pokrzywdzony i obwiniony. W latach 2011-2016 Naczelny Rzecznik Odpowiedzialności Zawodowej złożył trzy kasację oraz Prezes Naczelnej Rady Lekarskiej dwie. Natomiast minister zdrowia do tej pory nie skorzystał ze swojego prawa.

\begin{tabular}{|l|c|c|c|c|c|c|c|}
\hline & $\begin{array}{c}2011 \\
(6)\end{array}$ & $\begin{array}{c}2012 \\
(4)\end{array}$ & $\begin{array}{c}2013 \\
(7)\end{array}$ & $\begin{array}{c}2014 \\
(4)\end{array}$ & $\begin{array}{c}2015 \\
(7)\end{array}$ & $\begin{array}{c}2016 \\
(18)\end{array}$ \\
\hline \multicolumn{7}{|c|}{ Kto składał kasację } \\
\hline Pełnomocnicy pokrzywdzonych & 1 & 3 & 2 & 0 & 2 & 2 \\
\hline Obrońcy obwinionych & 4 & 1 & 4 & 3 & 3 & 15 \\
\hline Pokrzywdzona & 1 & & & & & \\
\hline Prezes NRL & & & 1 & 1 & & \\
\hline $\begin{array}{l}\text { Naczelny Rzecznik } \\
\text { Odpowiedzialności Zawodowej }\end{array}$ & & & & & 2 & 1 \\
\hline
\end{tabular}

Tabela 1. Opracowanie własne.

Kolejnym warunkiem dopuszczalności wniesienia kasacji jest wymóg posiadania przez stronę tzw. gravamen. Oznacza to, że strona wnosząca kasację musi mieć interes prawny we wniesieniu tego typu środka, a więc uzasadnione przekonanie, że wydane ostatecznie orzeczenie narusza jej interes prawny. Ocena istnienia gravamen ma charakter zobiektywizowany i opiera się na kryterium odwołującym się do roli procesowej strony skarżącej ${ }^{19}$. Ze względu na gravamen kasację można wnieść na korzyść obwinionego lekarza lub na jego niekorzyść.

Jednak kasacja złożona na niekorzyść podlega pewnym ograniczeniom. W postępowaniu karnym nie jest dopuszczalne uwzględnienie kasacji na

${ }^{19}$ M. Rogacka-Rzewnicka: Kasacja w polskim procesie karnym, Warszawa 2001, s. 107-108 
niekorzyść oskarżonego jeżeli została wniesiona po upływie roku od daty uprawomocnienia się orzeczenia ${ }^{20}$. W przypadku obwinionego lekarza ten termin jest krótszy i wynosi sześć miesięcy od daty uprawomocnienia się orzeczenia sądu II instancji (art. 96 ust. 2 ustawy o izbach lekarskich). Termin ten nie podlega przywróceniu. Wniesienie kasacji po upływie tego terminu powoduje, że kasacja powinna zostać rozpoznana, ale nie może zostać uwzględniona na niekorzyść obwinionego. Taka kasacja podlega oddaleniu (art. $537 \$ 1$ k.p.k.). Możliwość rozpoznania merytorycznie kasacji na niekorzyść, wniesionej po tym terminie istnieje tylko pod warunkiem, że w realiach sprawy możliwe jest „przełamanie” kierunku kasacji i rozstrzygnięcie na korzyść obwinionego (art. 518 k.p.k. w zw. z art. $434 \$ 2$ k.p.k. ). Jeżeli taka możliwość nie istnieje, to kasacja już w momencie jej wniesienia jest niedopuszczalna, albowiem nie został wówczas spełniony jedyny warunek merytorycznego rozpoznania takiego nadzwyczajnego środka zaskarżenia tj. możliwości poprawy sytuacji osoby, na której korzyść wniesiono kasację $e^{21}$. Z uwagi na charakter terminu wskazanego w art. $524 \$ 3$ k.p.k., a zatem także i terminu wskazanego w art. 96 ust. 2 ustawy o izbach lekarskich w orzecznictwie Sądu Najwyższego wskazuje się, że opóźnienie doręczenia uzasadnienia sądu II instancji nie może ograniczać prawa stron do wniesienia kasacji. "Skarżący może wystąpić z kasacją nie dysponując jeszcze uzasadnieniem, gdy termin ów zbliża się ku końcowi - opieszałość sądu nie może bowiem odbierać mu możliwości wystąpienia z kasacją, a wskazany termin przywróceniu nie podlega. Po otrzymaniu uzasadnienia, nawet gdy nastąpiło to po upływie omawianego terminu, strona może uzupełnić kasację"22.

W dotychczasowej praktyce Sądu Najwyższego podmiotem, który skarżył orzeczenia sądu lekarskiego w zakresie rozstrzygnięcia o karze na niekorzyść obwinionego lekarza był Naczelny Rzecznik Odpowiedzialności Zawodowej

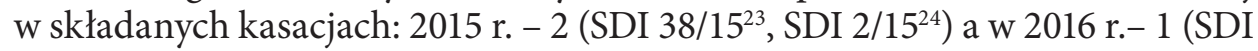
$\left.31 / 16^{25}\right)$. Rzecznik zarzucał rażącą niewspółmierność kary, wyrażającą się w wymierzeniu obwinionemu kary nadmiernie łagodnej w stosunku do przypisanego mu przewinienia zawodowego. W związku z tym wnosił o uchylenie zaskarżonego orzeczenia w zakresie rozstrzygnięcia o karze i przekazanie sprawy w tym zakresie Naczelnemu Sądowi Lekarskiemu do ponownego rozpoznania

\footnotetext{
${ }^{20}$ Art. $524 \$ 3$ k.p.k. w brzmieniu ustawy z dnia 11 marca 2016 r. (Dz. U. z 2016, poz. 437), która weszła w życie 15 kwietnia 2016 r.

${ }^{21}$ W. Kozielewicz, Odpowiedzialność dyscyplinarna sędziów, prokuratorów, adwokatów, radców prawnych i notariuszy, Warszawa 2016, s. 111

22 Postanowienie Sądu Najwyższego z dnia 17 grudnia 2013 r., sygn. akt SDI 49/13, Legalis Numer 745476

${ }^{23}$ Wyrok Sądu Najwyższego z dnia 29 września 2015 r., sygn. akt SDI 38/15, Legalis Numer 1337383

${ }^{24}$ Wyrok Sądu Najwyższego z dnia 19 marca 2015 r., sygn. akt SDI 2/15, Legalis Numer 1213097

${ }^{25}$ Wyrok Sądu Najwyższego z dnia 23 września 2016 r., sygn. akt SDI 31/16, Legalis Numer 1507535
} 
w postępowaniu odwoławczym. Na tej samej podstawie złożył kasację Prezes Naczelnej Rady Lekarskiej, który zaskarżył orzeczenie Naczelnego Sądu Lekarskiego na niekorzyść obwinionego, w części dotyczącej rozstrzygnięcia o karze, z jednoczesnym wskazaniem na jej rażącą niewspółmierność (wyrażającą się w nadmiernej łagodności), a wynikającą z braku rozważenia i uwzględnienia przez ten Sąd ustawowych dyrektyw wymiaru kary określonych w art. 53 k.k. Według Sądu Najwyższego rację ma skarżący podkreślając w kasacji brak odniesienia się sądu odwoławczego do takich aspektów zachowania obwinionego, jak obowiązek szczególnej troski o dobro małoletnich pacjentów przebywających pod jego opieką oraz wielokrotność podejmowanych przez niego działań mających charakter czynu zabronionego i deliktu dyscyplinarnego ${ }^{26}$. W kolejnej kasacji, którą wywiódł Prezes Naczelnej Rady Lekarskiej, zarzucił naruszenie bezwzględnej przesłanki odwoławczej art. $439 \$ 1$ pkt 5 k.p.k. w zw. $\mathrm{z}$ art. 112 pkt 1 ustawy o izbach lekarskich, polegające na wymierzeniu kary nieznanej ustawie ${ }^{27}$.

\section{Zwiększenie ochrony sądowej. Wyrok Trybunału Konstytucyjnego}

Krokiem do zwiększenia ochrony sądowej nad orzecznictwem sądów lekarskich była realizacja zaleceń wyroku Trybunału Konstytucyjnego ${ }^{28}$, który za naruszające standardy wyznaczone przez Konstytucję, uznał pozbawienie lekarza możliwości kwestionowania całego postępowania przed sądem dyscyplinarnym, jak również wymierzonej w tym postępowaniu kary. W poprzednio obowiązującej ustawie o izbach lekarskich art. 42 ust. $2^{29}$ wyłączał prawo lekarza, ukaranego przez Naczelny Sąd Lekarski w drugiej instancji karą upomnienia lub nagany, do wniesienia odwołania do sądu mimo, że kara ta niosła za sobą konsekwencje natury prawnej dla lekarza, wobec którego ją orzeczono. Możliwość taka istniała jedynie w stosunku do lekarza ukaranego karą zawieszenia prawa wykonywania zawodu lub karą pozbawienia prawa wykonywania zawodu. Na rozprawie przed Trybunałem Konstytucyjnym Marszałek Sejmu powołał się na wyrok Sądu Najwyższego z 7 kwietnia 1999 r., ${ }^{30}$ który podkreśl, że po wejściu w życie

\footnotetext{
${ }^{26}$ Wyrok Sądu Najwyższego z dnia 7 lutego 2014 r., sygn. akt SDI 52/13, Legalis Numer 768704

27 Wyrok Sądu Najwyższego z dnia 17 grudnia 2013 r., sygn. akt SDI 47/13, Legalis Numer 753859

${ }^{28}$ Wyrok Trybunału Konstytucyjnego z dnia 29 czerwca 2010, sygn. akt P 28/09, OTK Z. U. Nr 5A, poz. 52

${ }^{29}$ Ustawa z dnia 17 maja 1989 r. o izbach lekarskich (Dz. U. Nr 30, poz. 158 z późn. zm) - nieobowiązująca

${ }^{30}$ Wyrok Sądu Najwyższego z 7 kwietnia 1999 r sygn. akt I PKN 648/98, LEX nr 37708
} 
Konstytucji nie jest możliwe zamknięcie lub ograniczenie możliwości odwołania od wyroków organów dyscyplinarnych drugiej instancji. W tej sytuacji Sąd Najwyższy konsekwentnie stoi na stanowisku, że od każdego orzeczenia organu dyscyplinarnego kończącego postępowanie w sprawie przewinienia zawodowego powinna istnieć możliwość złożenia odwołania do sądu powszechnego. Do identycznego wniosku prowadzi analiza orzecznictwa Europejskiego Trybunału Praw Człowieka a przede wszystkim wyrok w sprawie Le Compte, Van Leuven i De Meyere przeciwko Belgii ${ }^{31}$. Sprawa dotyczyła m.in. zawieszenia prawa wykonywania zawodu lekarzowi na okres 6 tygodni przez organ dyscyplinarny. Jednak Sąd Kasacyjny, gdzie można było składać skargi od orzeczeń organów dyscyplinarnych mógł je badać jedynie pod kątem formalnym, natomiast nie mógł rozważać innych kwestii np. dotyczących wysokości kary. ETPC podkreślił, że art. 6 ust. 1 Konwencji o ochronie praw człowieka i podstawowych wolności ${ }^{32}$ nie wymaga aby na każdym etapie postępowania sprawa była rozpatrywana przez organ stricte sądowy, ale rozstrzygnięcia tego rodzaju organów powinny zostać poddane faktycznej i prawnej kontroli organu mającego wszelkie znamiona sądu. Istotne są takie cechy jak: niezawisłość i bezstronność członków wchodzących w skład organów, trwały charakter ich funkcji oraz istnienie gwarancji proceduralnych dla stron. W wyroku Frankowicz przeciwko Polsce ETPC pozytywnie ocenił organizację sądów lekarskich wskazując, iż nie ma wątpliwości, co do ich niezależności. Sędziowie takich sądów są wybierani z pośród lekarzy na okres czterech lat i działają w sądzie, nie jako reprezentanci jakiegoś konkretnego ośrodka lekarskiego, lecz w swoim własnym imieniu. W związku z powyższym Trybunał uznał brak naruszenia art. 6 ust. 1 Konwencji ${ }^{33}$

Obowiązująca od dnia 1 stycznia 2010 r. ustawa o izbach lekarskich przewiduje, że od prawomocnego orzeczenia sądu lekarskiego kończącego postępowanie w sprawie przysługuje kasacja do Sądu Najwyższego. Zatem obecnie obowiązująca ustawa nie wprowadza żadnych ograniczeń uzależniających wniesienie kasacji od rodzaju czy surowości kary orzeczonej przez sąd lekarski. Jednak pomimo tych nowych regulacji prawo do drogi sądowej w postępowaniu w przedmiocie odpowiedzialności zawodowej lekarz było w pewnym stopniu ograniczone. Co do zasady w postępowaniu karnym art. $520 \$ 2$ k.p.k. ogranicza możliwość wnoszenia kasacji od orzeczenia sądu odwoławczego przez stronę, która nie zaskarżyła orzeczenia sądu pierwszej instancji. Oznacza to, że strona, która nie zaskarżyła orzeczenia sądu I instancji, nie może wnieść kasacji od orzeczenia sądu odwoławczego, jeżeli orzeczenie sadu I instancji utrzymano w mocy

31 Wyrok ETPC z dnia 23 czerwca 1981 r., w sprawie Le Compte, Van Leuven i De Meyere przeciwko Belgii, nr 6878/75 i 7238/75

32 Konwencja o ochronie praw człowieka i podstawowych wolności z dnia 4 listopada 1950 r., (Dz. U. z 1993 r., Nr 6 poz. 284 ze zm.)

${ }^{33}$ Wyrok ETPC z dnia 18 grudnia 2008 r., w sprawie Frankowicz przeciwko Polsce, nr 53025/99 
lub zmieniono na jej korzyść. Zatem strona może wnieść kasację tylko wtedy, gdy w wyniku wniesienia środka odwoławczego przez inną stronę procesową orzeczenie sądu pierwszej instancji zostało przez sąd ad quem zmienione na jej niekorzyść. Analogiczne rozwiązanie znajdował się w ustawie o izbach lekarskich w art. 95 uchylono ust. 2 i 3. Jednak Trybunał Konstytucyjny ${ }^{34}$ uznał, że odniesienie treści art. 520 k.p.k. do postępowania w przedmiocie odpowiedzialności zawodowej postępowania pozasądowego $\mathrm{w}$ dwóch etapach, stanowi ograniczenie prawa do sądu. Trybunał Konstytucyjny wskazał również, że celem sądowej kontroli działań organów dyscyplinarnych jest weryfikacja prawidłowości całego postępowania dyscyplinarnego, a nie tylko wymierzonej w tym procesie kary. Podmiot kwestionujący orzeczenie dyscyplinarne powinien mieć możliwość kwestionowania przed sądem zarówno samego faktu popełnienia przewinienia zawodowego, dopuszczalność jego wszczęcia, prawidłowość postępowania dyscyplinarnego, jak i kary. $Z$ tego względu należało usunąć przepisy art. 95 ust. 2 i 3 ustawy o izbach lekarskich. Takie rozwiązanie likwiduje ograniczenie drogi do sądu stronie, która nie zaskarżyła orzeczenia sądu dyscyplinarnego pierwszej instancji, a jednocześnie stanowi element nadzoru państwa nad działalnością samorządu zawodowego zawodów zaufania publicznego.

\section{Podstawy kasacji. Wybrane orzeczenia Sądu Najwyższego}

Efektywną ochronę sądową orzeczeń sądów lekarskich zapewnia fakt, że wzruszenie prawomocnego orzeczenia w drodze nadzwyczajnego środka zaskarżenia - kasacji, jest możliwe jedynie w wypadku stwierdzenia istnienia uchybień zwanych w literaturze „podstawami kasacji”. Przez „podstawy kasacji” należy rozumieć okoliczności, na których można oprzeć wniesienie omawianego środka prawnego. Uchybienia, na których można oprzeć kasację, mają postać wad prawnych, których cechą charakterystyczną jest ich rażący charakter ${ }^{35}$. Podstawy kasacyjne w ustawie o izbach lekarskich różnią się od podstaw w procedurze karnej wymienionych w art. 523 k.p.k. Mają one charakter w pełni samodzielny i autonomiczny, w związku z tym nie mogą być „uzupełniane” $\mathrm{w}$ drodze odpowiedniego stosowania. Wśród przyczyn kasacyjnych $\mathrm{z}$ art. 96 ust. 1 ustawy o izbach lekarskich należy wyróżnić trzy grupy:

34 Opinia Prokuratora Generalnego do projektu ustawy o zmianie ustawy o izbach lekarskich (druk nr 520), Druk nr PG VII G 025/187/12 z 12 lipca 2012 r.

${ }^{35}$ M. Rogacka-Rzewnicka, Kasacja w polskim procesie karnym, Warszawa 2001, s. 214-215 
- z powodu uchybień wymienionych w art. $439 \$ 1$ k.p.k.,

- innego rażącego naruszenia prawa,

- z powodu niewspółmierności kary.

Po pierwsze kasacja od orzeczenia Naczelnego Sądu Lekarskiego może być wniesiona z powodu uchybień wymienionych w art. $439 \$ 1$ k.p.k. określanych w doktrynie jako bezwzględne przyczyny odwoławcze. Naruszenia prawa, o których mowa w tym przepisie sama ustawa traktuje jako najpoważniejsze, które powodują konieczność uchylenia zaskarżonego orzeczenia bez badania ich wpływu na treść orzeczenia ${ }^{36}$. Należy podkreślić, że wymienione w art. $439 \$ 1$ k.p.k. podstawy kasacyjne różnią się od pozostałych podstaw wieloma istotnymi cechami. Uwzględnia się je niezależnie od granic zaskarżenia i podniesionych zarzutów, zatem także wtedy, gdy dostrzeżono je przy środku odwoławczym niezaskarżającym całości orzeczenia i niezależnie od tego, czy strona podnosiła taki zarzut, a więc i z urzędu ${ }^{37}$. Bezwzględne przyczyny odwoławcze zachodzą zarówno wówczas, gdy uchybienia wymienionego w art. $439 \$ 1$ k.p.k. dopuścił się sąd odwoławczy, jak i wówczas gdy sąd ten wbrew nakazowi wynikającemu z tego przepisu, nie uchylił orzeczenia sądu pierwszej instancji dotkniętego takim uchybieniem ${ }^{38}$.

Uchybienia $\mathrm{z}$ art. $439 \$ 1$ k.p.k. należy interpretować możliwie ściśle z uwzględnieniem wskazań płynących $\mathrm{z}$ naczelnych zasad procesowych i rozwiązań zawartych $\mathrm{w}$ innych przepisach kodeksu ${ }^{39}$ oraz przepisów ustawy o izbach lekarskich, która wprost odsyła do tego przepisu.

Wymienione w tym przepisie przesłanki były przedmiotem rozważań Sądu Najwyższego, który rozpatrywał kasacje od orzeczeń sądów lekarskich. Jedno z uchybień dotyczyło m.in. orzeczenie kary, środka karnego lub zabezpieczającego nieznanego ustawie. Sąd Najwyższy w wyroku z 17 grudnia 2013 r. ${ }^{40}$, rozpoznał kasację w której skarżący zarzucił rażące naruszenie art. 83 ust. 1 pkt 6 ustawy o izbach lekarskich w zw. z art. $439 \$ 1$ pkt 5 k.p.k. w zw. z art. 112 pkt 1 ustawy o izbach lekarskich, polegające na wymierzeniu kary nieznanej ustawie. Okręgowy Sąd Lekarski uznał dr n. med. I. B. za winnego tego, że jako lekarz kierujący zespołem karetki Pogotowia Ratunkowego, udzielając pomocy popełnił błąd w sztuce lekarskiej w ten sposób, że w chwili wystąpienia

\footnotetext{
${ }^{36}$ Wyrok Sądu Najwyższego z dnia 31 sierpnia 2011 r., sygn. akt II KK 99/11, LEX nr 898597

${ }^{37}$ T. Grzegorczyk, Kodeks postępowania karnego. Tom I. Artykuły 1-467. Art. 439 Bezwzględne przyczyny odwoławcze, Komentarz LEX 2014

${ }^{38}$ Wyrok Sądu Najwyższego z dnia 10 sierpnia 2000 r., sygn. akt III KKN 287/00, OSNKW 2000, nr 9-10, poz. 86

${ }^{39}$ Postanowienie Sądu Najwyższego z dnia19 marca 1977 r., sygn. akt II KZ 55/77, OSNKW 1977, z. 4-5, poz.46; Postanowienie z dnia 19 kwietnia 2005 r., sygn. akt II KO 75/04, OSNKW 2005, z. $7-8$, poz. 70

${ }^{40}$ Wyrok Sądu Najwyższego z dnia 17 grudnia 2013 r. sygn. akt SDI 47/13, Legalis Numer 753859
} 
u pacjenta nagłego zatrzymania krążenia i zatrzymania oddychania nie wykonał intubacji i nie zastosował wsparcia oddechowego, a następnie nie zastosował farmakoterapii, co mogło przyczynić się do stanu bezpośredniego zagrożenia zdrowia i życia, za to wymierzył mu karę zawieszenia prawa wykonywania zawodu na okres roku. W instancji odwoławczej Naczelny Sąd Lekarski zmienił zaskarżone orzeczenie i wymierzył obwinionemu karę zawieszenia prawa wykonywania zawodu lekarza na okres sześciu miesięcy. Od prawomocnego orzeczenia Naczelnego Sądu Lekarskiego kasację wywiódł Prezes Naczelnej Rady Lekarskiej. Zdaniem Sądu Najwyższego kasacja zasługiwała na uwzględnienie, ale nie jest trafny był zarzut zaistnienia uchybienia przewidzianego w art. 439 $\$ 1$ pkt 5 k.p.k., gdyż kara zawieszenia prawa wykonywania zawodu lekarza jest znana ustawie. Jednak zaskarżone orzeczenie zapadło $\mathrm{z}$ rażącą obrazą art. 83 ust. 1 pkt 6 ustawy o izbach lekarskich, który stanowi, iż kara zawieszenia prawa wykonywania zawodu wymierzana jest $w$ granicach od roku do lat 5 . Tym samym Naczelny Sąd Lekarski wymierzając obwinionemu karę 6 miesięcy zawieszenia prawa wykonywania zawodu, rażąco naruszył ten przepis, co miało wpływ na treść orzeczenia.

Inną bezwzględną przesłanką odwoławczą jest stwierdzenie, że udział w wydaniu orzeczenia brała osoba nieuprawniona (np. orzeka osoba, która nie została wybrana przez okręgowy zajazd lekarzy) lub niezdolna do orzekania (np. z powodu choroby) bądź podlegająca wyłączeniu na podstawie art. 40 k.p.k., który stanowi o wyłączeniu sędziego ex lege. Wyłączenie sędziego z mocy prawa ma charakter wyjątkowy. U podstaw tego wyłączenia leży uznanie, że w wypadkach wskazanych w ustawie sędzia $\mathrm{z}$ założenia może nie być bezstronny ze względu na własny interes, interes osób mu bliskich (art. $40 \$ 1$ pkt 1, 2 i 3 k.p.k.), z uwagi na to, że występował wcześniej w danym postępowaniu w określonej roli procesowej (art. $40 \$ 1$ pkt 4, 5, 10 k.p.k.) lub brał udział w podjęciu decyzji procesowej, która w dalszym toku procesu została zaskarżona lub uchylona (art. $40 \$ 1$ pkt 6, 7, 9 i art. $40 \$ 3$ k.p.k. $)^{41}$. Powyższą przesłankę rozważał Sąd Najwyższy ${ }^{42}$ w sprawie, w której członkiem składu Okręgowego Sądu Lekarskiego, orzekającego w przedmiocie odpowiedzialności zawodowej obwinionego lekarza dentysty R. M., była lekarz dentysta K. P. Jak wynika z dołączonej do akt sprawy i dokumentacji leczenia w Wojewódzkiej Poradni Stomatologicznej, lekarz dentysta K. P. w dniach 30 sierpnia, 18 września oraz 25 października 2007 r. udzielała pokrzywdzonemu pacjentowi pomocy specjalistycznej, przeprowadzając w ramach podjętych czynności nie tylko wywiad z pacjentem, ale i stwierdzając różnego rodzaju dolegliwości. Zdaniem Sądu Najwyższego nie może budzić wąt-

\footnotetext{
${ }^{41}$ Wyrok Trybunału Konstytucyjnego z dnia 16 kwietnia 2015 r. sygn. akt SK 66/13, (Dz. U. z 2015 poz.560 )

${ }^{42}$ Wyrok Sądu Najwyższego z dnia 4 stycznia 2011r., sygn. akt SDI 30/10 Legalis Numer 417469
} 
pliwości, że poczyniła ona istotne spostrzeżenia w przedmiocie stanu uzębienia i przebiegu procesu leczenia pokrzywdzonego pacjenta. Zatem za bezsporne uznać należy, że wyżej wymieniona lekarz dentysta K.P. była „świadkiem czynu, o który sprawa się toczy" w rozumieniu art. $40 \$ 1$ pkt 4 k.p.k., a tym samym podlegała wyłączeniu od udziału w niniejszej spawie ex lege. Nie powinna być powołana w skład Okręgowego Sądu Lekarskiego, orzekającego w przedmiocie odpowiedzialności zawodowej obwinionego lekarza dentysty R. M. Sąd Najwyższy podkreślił, że sędzia jest powołany do oceny wiarygodności świadków, wobec czego nie może łączyć w jednej osobie obu tych ról, gdyż zawsze wtedy może wystąpić ryzyko, że był subiektywnie przekonany o prawdziwości swoich spostrzeżeń, mimo że mogą one obiektywnie nie odpowiadać rzeczywistości.

Ustawa o izbach lekarskich stanowi, że obok bezwzględnych przyczyn odwoławczych można wnieść kasacje z powodu innych rażących naruszeń prawa. W tym zakresie pomocna jest reguła interpretacyjna w myśl której „rażącym naruszeniem prawa" będzie takie uchybienie, którego skutkiem jest pogorszenie sytuacji skazanego w porównaniu do tej w której znalazłby się, gdyby odpowiednie przepisy zastosowano w sposób prawidłow $y^{43}$. Jednak w przeciwieństwie do Kodeksu postępowania karnego ustawa o izbach lekarskich nie wymaga, aby naruszenie prawa „rażące” miało jednocześnie „istotny” wpływ na treść orzeczenia. Ponadto „rażące naruszenie prawa” dotyczy zarówno naruszenia prawa materialnego, jak i procesowego. $\mathrm{W}$ aspekcie procesowym przedmiotem rozważań Sądu Najwyższego była jedna z podstawowych zasad gwarancyjnych procesu karnego ${ }^{44}$ zawarta w art. 434 k.p.k. Zgodnie z ta zasadą oskarżony może bowiem w sposób nieskrępowany realizować swoje prawo do obrony, nie obawiając się, że zostanie wydane orzeczenie surowsze niż to które zaskarżył wnosząc środek odwoławczy ${ }^{45}$. W sprawie rozpatrywanej 23 września 2016 r. Sąd Najwyższy zajmował się znaczeniem pośredniego zakazu reformationis in peius wyrażonego $\mathrm{w}$ art. 443 k.p.k., mającego $\mathrm{w}$ związku z treścią art. 112 pkt 1 ustawy o izbach lekarskich in concreto zastosowanie w odpowiedzialności zawodowej lekarzy. Zdaniem Sądu Najwyższego „wydanie „orzeczenia surowszego" po uchyleniu orzeczenia i przekazaniu sprawy do ponownego rozpoznania jest dopuszczalne w dalszym postępowaniu tylko wówczas, gdy uchylenie to nastąpiło na skutek uwzględnienia środka odwoławczego wniesionego na niekorzyść obwinionego i to jedynie w granicach zaskarżenia na niekorzyść lub gdy uchylenie nastąpiło z mocy samej ustawy, niezależnie od granic zaskarżenia (art. $439 \$ 1$ i 2 k.p.k. art. 440 k.p.k.)"36. W rozpoznawanej

\footnotetext{
${ }^{43}$ Postanowienie Sądu Najwyższego z dnia 25 lutego 2014 r., sygn. akt IV KK 6/14, LEX 1444343

${ }^{44}$ Wyrok Sądu Najwyższego z dnia 30 października 2015 r., sygn.. akt IV KK 248/15, LEX 1818232

${ }_{45}$ T. Boratyńska, P. Czarnecki, Kodeks postepowania karnego - komentarz, w: A. Sakowicz [red.], Warszawa 2016, s. 990

${ }^{46}$ Wyrok Sądu Najwyższego z dnia 23 września 2016 r. sygn.. akt SDI 50/15, Legalis Numer 1507538
} 
sprawie tego zakazu nie respektowano. W świetle przytoczonych faktów Sąd Najwyższy nie ma wątpliwości, że wymierzona wobec obwinionego w ponownym postępowaniu przed Okręgowym Sądem Lekarskim kara pieniężna jest karą surowszą, aniżeli wymierzona za to samo przewinienie zawodowe w toku pierwszego (wcześniejszego) postępowania, kara upomnienia. „Świadczy o tym nie tylko sam charakter obydwu tych kar samoistnie pozwalający o tym wnioskować (kara pieniężna, co wynika z jej istoty, jest realną dolegliwością finansową dla sprawcy; kara upomnienia takich skutków nie powoduje i stanowi przez swój li tylko „upominający” status dolegliwość moralną, pozbawioną aspektów uszczuplania mienia sprawcy i praktycznie nie wiążącą się z żadną innego rodzaju dolegliwością wymierzoną lekarzowi)" ${ }^{\prime 37}$. Naczelny Sąd Lekarski II instancji nie dostrzegł tego uchybienia rozpatrując odwołanie obwinionego od orzeczenia, które zapadło przy ponownym rozpoznaniu sprawy i było dla obwinionego lekarza surowsze. Należy zaznaczyć, że w odwołaniu od ponownego orzeczenia Okręgowego Sądu Lekarskiego I instancji zarzut naruszenia art. 443 k.p.k. nie był podniesiony. Jednak zdaniem Sądu Najwyższego oczywiste jest to, iż Naczelny Sąd Lekarski jako Sąd Odwoławczy dostrzegając to uchybienie skutkujące rażącą niesprawiedliwością orzeczenia, w rozumieniu art. 440 k.p.k., zobowiązany był rozpoznać to odwołanie w zakresie szerszym, stosownie do wskazań art. $433 \$ 1$ in fine k.p.k.. Powyższe uchybienie Sądu Odwoławczego miało istotny wpływ na treść zaskarżonego orzeczenia, bo w jego następstwie doszło do wymierzenia obwinionemu lekarzowi surowszej kary, co z punktu widzenia ochrony i gwarancji art. 443 k.p.k. jest niedopuszczalne.

Trzecią grupę przesłanek kasacyjnych z ustawy o izbach lekarskich stanowi niewspółmierność kary. Odmiennie niż w Kodeksie postępowania karnego jest to samodzielna podstawa kasacyjna. Do tej pory w procedurze karnej zgodnie $\mathrm{z}$ art. $523 \$ 1$ k.p.k. nie można było wnieść kasacji tylko z powodu niewspółmierności kary. Jednak ostanie zmiany k.p.k. zniosły to ograniczenie w stosunku do kasacji wniesionej przez Ministra Sprawiedliwości - Prokuratora Generalnego w sprawach o zbrodnie ${ }^{48}$. W sprawach lekarskich Sąd Najwyższy analizował orzeczenie, które zaskarżone zostało kasacją ${ }^{49}$ Naczelnego Rzecznika Odpowiedzialności Zawodowej, w której podniesiono zarzut rażącego naruszenia art. 83 ust. 1 pkt 6 ustawy o izbach lekarskich w zw. z art. $53 \$ 1$ i 2 k.k. w zw. z art. 112 pkt 2 ustawy o izbach lekarskich polegające na wymierzeniu kary rażąco niewspółmiernej do przypisanego obwinionemu przewinienia zawodowego. Ważną kwestia jest fakt, że Okręgowy Sąd Lekarki oceniając zachowanie obwinionego lekarza i wymierzając mu karę zwrócił uwagę na bardzo wysoki stopień

${ }^{47}$ Wyrok Sądu Najwyższego z 23 września 2016 r. sygn.. akt SDI 50/15, Numer 1507538 Legalis

48 Art. $523 \$$ 1a k.p.k. w brzmieniu ustawy z dnia 11 marca 2016 r. (Dz. U. z 2016, poz. 437), która weszła w życie 15 kwietnia 2016 r.

${ }^{49}$ Wyrok Sądu Najwyższego z 29 września 2015 r., SDI 38/15, Numer 1337383 Legalis 
naruszenia obowiązków zawodowych. Tym samym stopień społecznej szkodliwości przypisanego czynu ocenił jako bardzo wysoki. Okręgowy Sąd Lekarski wskazał, że obwiniony lekarz drastycznie naruszył stosunek zaufania jaki powinien łączyć lekarza i pacjenta i w związku z tym nie może być dopuszczony do dalszego wykonywania zawodu. Naczelny Sąd Lekarski w instancji odwoławczej nie zakwestionował prawidłowości ustaleń poczynionych przez Okręgowy Sąd Lekarski I instancji oraz stopnia zawinienia i przyjętego stopnia społecznej szkodliwości czynu. Pomimo tego Naczelny Sąd Lekarski orzeczeniem z dnia 9 maja 2014 r. zmienił orzeczenie, I instancji wymierzając karę łagodniejszą tj. karę zawieszenia prawa wykonywania zawodu lekarza na okres 5 lat. Jako jedyną okoliczność łagodzącą Naczelny Sąd Lekarski wskazał dotychczasową niekaralność obwinionego, choć była to okoliczność znana i Sądowi I instancji. Zdaniem Sądu Najwyższego elementarnym obowiązkiem Sądu Odwoławczego jest wskazanie w sporządzanym uzasadnieniu swego orzeczenia tego, czym kierował się wydając swoje orzeczenie oraz dlaczego zarzuty odwołania uznał za zasadne albo niezasadne (art. $457 \$ 3$ k.p.k. w zw. $z$ art. 112 pkt 1 ustawy o izbach lekarskich). W niniejszej sprawie brak było takiego uzasadnienia i dlatego nie wiadomo, dlaczego doszło do zmiany zaskarżonego orzeczenia.

Strony postępowania przed sądami lekarskimi coraz chętniej wykorzystują ten nadzwyczajny środek odwoławczy jakim jest kasacja. Poniżej tabela przedstawia statystykę kasacji od orzeczeń sądów lekarskich w latach 2011-2016.

\begin{tabular}{|l|c|c|c|c|c|c|c|}
\hline & $\begin{array}{c}2011 \\
(6)\end{array}$ & $\begin{array}{c}2012 \\
(4)\end{array}$ & $\begin{array}{c}2013 \\
(7)\end{array}$ & $\begin{array}{c}2014 \\
(4)\end{array}$ & $\begin{array}{c}2015 \\
(7)\end{array}$ & $\begin{array}{c}2016 \\
(18)\end{array}$ \\
\hline $\begin{array}{l}|l| \\
\text { SN uchylił zaskarżone orzeczenie i przekazał } \\
\text { sprawę do ponownego rozpoznania }\end{array}$ & 1 & 2 & 3 & 1 & 5 & 2 \\
\hline SN oddala kasację & 2 & 2 & 3 & 2 & 1 & 14 \\
\hline SN umorzył postępowanie & 1 & 2 & & & 1 & 1 \\
\hline SN pozostawia bez rozpoznania & 1 & & 1 & & 1 & \\
\hline inne & 1 & & & 1 & & \\
\hline
\end{tabular}

Tabela nr 2. Wyniki postępowania kasacyjnego (w niektórych postępowaniach SN rozpatrywał więcej niż jeden zarzut). Opracowanie własne.

Analizując w szerszym zakresie, niż powyżej przytoczone wybrane przykłady, orzecznictwo Sądu Najwyższego w sprawach sądów dyscyplinarnych lekarzy należy podkreślić, że pomimo wzrastającej liczby kierowanych do Sądu 
Najwyższego spraw znaczna ich liczba to kasacje oddalone jako oczywiście bezzasadne. Świadczy to o pewnej stałości i trafności sądów lekarskich. Z drugiej strony analizując uchybienia najczęściej skutkującym uwzględnieniem kasacji to podobnie jak w sądach powszechnych obraza przepisów art. $433 \$ 2$ k.p.k. oraz art. $457 \$ 3$ k.p.k. W orzecznictwie Sądu Najwyższego dominuje pogląd, że brak w uzasadnieniu wyroku sądu odwoławczego ustosunkowania się do wszystkich zarzutów zwartych w rozpoznawanym środku odwoławczym stanowi potwierdzenie tezy, że doszło do naruszenia prawa. Oznacza to, że sąd odwoławczy w sposób „nierzetelny” (niepełny) rozpoznał ten środek odwoławczy. Według Sądu Najwyższego w uzasadnieniu orzeczenia sądu odwoławczego muszą znaleźć się rozważania odnoszące się wprost do zarzutów apelacji, z których jasno będzie wynikało, $\mathrm{z}$ jakich to powodów odwołujący ma rację lub jej nie $\mathrm{ma}^{50}$.

\section{Podsumowanie i wnioski}

Prawo do sądu w postępowaniu dyscyplinarnym chroni lekarza przed możliwością „uznaniowego" przypisania winy i wymierzenia kary, a także umożliwia mu oczyszczenie się z postawionych zarzutów. Realizacja tego prawa w zakresie prawa materialnego, jest oparta na ustawie o izbach lekarskich, Kodeksie Etyki Lekarskiej i innych aktach normatywnych organy samorządu zawodowego lekarzy, które mają charakter prawa wewnętrznie obowiązującego. W zakresie prawa procesowego postępowanie oparte jest natomiast na Kodeksie Karnym i na Kodeksie Postępowania Karnego. Wymiar sprawiedliwości w sprawach dyscyplinarnych, zgodnie z ustawą o izbach lekarskich, sprawują okręgowe sądy lekarskie, Naczelny Sąd Lekarski oraz Sąd Najwyższy jako instancja kasacyjna. Przeprowadzona w pracy analiza orzecznictwa sądów lekarskich w oparciu o orzeczenia Sądu Najwyższego prowadzi do kilku wniosków.

Ze względu na swoją funkcję kasacja w postępowaniu karnym ma charakter „nadzwyczajny”, gdyż jest instytucją procesową wykraczającą poza minimalny standard konstytucyjny, przewidujący co najmniej dwuinstancyjność „zwykłego” postępowania sądowego ${ }^{51}$. Model kasacji w postępowaniu dyscyplinarnym lekarzy podobnie jak $\mathrm{w}$ innych zawodach zaufania publicznego realizuje funkcję kontroli orzeczenia sądów lekarskich, niebędących jednak sądem w rozumieniu art. 176 ust. 1 Konstytucji.

50 W. Kozielewicz, O kasacji po 1 lipca 2015 r., [w:] Postepowanie odwoławcze, kasacyjne i wznowieniowe w nowym modelu procesu karnego, Studia i Analizy Sadu Najwyższego, tom II, Warszawa 2015, s. 53

51 R. Baszczuk, Kontrola sądowa nad postepowaniem dyscyplinarnym wobec adwokatów i aplikantów adwokackich, Palestra nr 1-2/2012, s. 92 
Kasacje wnoszone od prawomocnych orzeczeń sądów odwoławczych, w tym przypadku sądów lekarskich, nie służą kolejnej trzecioinstancyjnej kontroli poczynionych w sprawie ustaleń faktycznych, lecz tylko wychwyceniu rażących naruszeń prawa materialnego i procesowego ${ }^{52}$. $Z$ tego względu po opisanym powyżej wyroku Trybunału Konstytucyjnego z 29 czerwca 20110 r., kasacja w obecnie obowiązującej ustawie o izbach lekarskich przysługuje od każdego prawomocnego rozstrzygnięcia sądu lekarskiego, kończącego postępowanie w przedmiocie odpowiedzialności zawodowej lekarzy, które wydane zostało lub powinno było zostać wydane, $z$ uwagi na materię, której dotyczy, w formie orzeczenia" ${ }^{53}$. Należy tez podkreślić, że gruncie ustawy o izbach lekarskich pojęcie „orzeczenie" posiada znaczenie swoiste, odmienne od wykładni tego terminu na gruncie przepisów Kodeksu postępowania karnego, gdzie orzeczeniem określa się decyzje procesowe zarówno w postaci wyroków, jak i postanowień.

Trybunał Konstytucyjny wspomnianym już wyrokiem z dnia 25 czerwca 2012 r., uznał, iż zakres sądowej kontroli postępowania w trybie kasacji, jest znacznie szerszy niż w wypadku kasacji w sprawach karnych. Pomimo ostatniej nowelizacji Kodeksu postępowania karnego ${ }^{54}$ podstawy kasacji w sprawach dyscyplinarnych lekarzy różnią się swym zakresem. Kasacja w sprawach odpowiedzialności zawodowej lekarzy może być wniesiona z powodu rażącego naruszenia prawa jaki i rażącej niewspółmierności kary. Jak już wskazano, podstawy kasacyjne w postępowaniu dyscyplinarnym lekarzy zostały ujęte szerzej niż podstawy kasacji w postępowaniu karnym, co daje postawę do rzetelnej kontroli zaskarżonego orzeczenia.

Analizowana liczba kasacji dyscyplinarnych lekarzy niewątpliwie pokazuje, że w ostatnim czasie, szczególnie w zeszłym roku (2016) liczba kasacji od orzeczeń sądów lekarskich rośnie. Tym niemniej liczba oddalonych kasacji świadczy o stałości i jednolitości tego orzecznictwa. Należy zatem uznać, że przyjęty w ustawie o izbach lekarskich kasacyjny model kontroli orzecznictwa sądów lekarskich gwarantuje efektywna ochronę sądową.

\section{Literatura:}

Baszczuk R, Kontrola sądowa nad postepowaniem dyscyplinarnym wobec adwokatów i aplikantów adwokackich, „Palestra” 2012 nr 1-2, s. 92

${ }^{52}$ W. Kozielewicz, Odpowiedzialność dyscyplinarna sędziów, prokuratorów, adwokatów, radców prawnych i notariuszy, Warszawa 2016, s. 116

${ }^{53}$ Postanowienie Sądu Najwyższego z dnia 25 lutego 2011 r., sygn. akt SDI 4/11, Legalis Numer 428301

${ }^{\mathrm{P}}$ ostanowienie Sądu Najwyższego z dnia 10 maja 2012 r., sygn. akt VI KZ 2/12, Legalis Numer 492186

${ }^{54}$ Ustawa z dnia 11 marca 2016 r. (Dz. U. z 2016, poz. 437), która weszła w życie 15 kwietnia $2016 \mathrm{r}$. 
Boratyńska T, Czarnecki P, Kodeks postepowania karnego - komentarz, w: A. Sakowicz [red.], Warszawa 2016, s. 990

Czarnecki P, Postępowanie dyscyplinarne wobec osób wykonujących prawnicze zawody zaufania publicznego, Warszawa 2013, s. 370-373

Grzegorczyk T, [w:] Grzegorczyk T., Tylman J., Polskie postępowanie karne, wyd. 6, Warszawa 2007, s. 909

Grzegorczyk T, Kodeks postępowania karnego. Tom I. Artykuły 1-467. Komentarz LEX 2014

Kozielewicz W, Odpowiedzialność dyscyplinarna sędziów, prokuratorów, adwokatów, radców prawnych i notariuszy, Warszawa 2016, s. 111

Kozielewicz W, O kasacji po 1 lipca 2015 r., w: Postępowanie odwoławcze, kasacyjne i wznowieniowe w nowym modelu procesu karnego, "Studia i Analizy Sadu Najwyższego", tom II, Warszawa 2015, s. 53

Opinia Prokuratora Generalnego do projektu ustawy o zmianie ustawy o izbach lekarskich (druk nr 520), Druk nr PG VII G 025/187/12 z 12 lipca 2012

Rogacka-Rzewnicka M, Kasacja w polskim procesie karnym, Warszawa 2001, s.107-108; s. 214-215

Skorupka J. [red] Kodeks postępowania karnego - komentarz, Warszawa 2016, s. 1211

Zielińska E, Odpowiedzialność zawodowa lekarza i jej stosunek do odpowiedzialności karnej, Warszawa 2001, s. 322

\section{Akty prawne}

Konstytucja Rzeczpospolitej Polskiej z 2 kwietnia 1997 r. ( Dz. U. Nr 78, poz. 483)

Konwencja o ochronie praw człowieka i podstawowych wolności z dnia 4 listopada 1950 r. (Dz. U. z 1993 r., Nr 6 poz. 284 ze zm.)

Ustawa z dnia 17 maja 1989 r. o izbach lekarskich (Dz. U. Nr 30, poz. 158 z późn. zm) - nieobowiązująca Ustawa z dnia 26 maja 1982 r. Prawo o adwokaturze (Dz. U. z 2009 r. Nr 16, poz. 124 z późn. zm) Ustawa z dnia 6 lipca 1982 r. o radcach prawnych (Dz. U. Nr 9, poz. 145 z późn. zm.)

Ustawa z dnia 2 grudnia 2009 r. o izbach lekarskich (Dz. U. 2009 nr 219 poz. 1708 z późn. zm.)

Ustawa z dnia 11 marca 2016 r. o zmianie ustawy - Kodeks postępowania karnego oraz niektórych innych ustaw (Dz. U. z dnia 1 kwietnia 2016 r., poz. 437).

\section{Orzecznictwo}

Orzeczenie Trybunału Konstytucyjnego z dnia 1 marca 1994 r., sygn. akt. U 7/93, Legalis Numer 10199 oraz

Orzeczenie Trybunału Konstytucyjnego z dnia 26 kwietnia 1995 r., sygn. akt. K 11/94, Legalis Numer 10252

Orzeczenie Trybunału Konstytucyjnego z dnia 8 grudnia 1998 r., sygn. akt. K 41/97, Legalis Numer 10465

Postanowienie Sądu Najwyższego z dnia19 marca 1977 r., sygn. akt Il KZ55/77, OSNKW 1977, z. 4-5, poz.46 Postanowienie Sądu Najwyższego z dnia 11 lutego 2008 sygn. akt SDI 1/08, OSNKW 2008 nr 4, poz. 30 Postanowienie z dnia 19 kwietnia 2005 r., sygn. akt II KO 75/04, OSNKW 2005, z. 7-8, poz. 70 Postanowienie Sądu Najwyższego z dnia 25 lutego 2011 r., sygn. akt SDI 4/11, Legalis Numer 428301 Postanowienie Sądu Najwyższego z dnia 10 maja 2012 r., sygn. akt VI KZ 2/12, Legalis Numer 492186 Postanowienie Sądu Najwyższego z dnia 17 grudnia 2013 r., sygn. akt SDI 49/13, Legalis Numer 745476 Postanowienie Sądu Najwyższego z dnia 25 lutego 2014 r., sygn. akt IV KK 6/14, LEX 144434 
Wyrok ETPC z dnia 23 czerwca 198 r. w sprawie Le Compte, Van Leuven i De Meyere przeciwko Belgii, $\mathrm{nr}$ 6878/75 i 7238/75

Wyrok Trybunału Konstytucyjnego z dnia 16 marca 1999 r., sygn.akt SK 19/98, OTK 1999 nr 3, poz. 36 Wyrok Trybunału Konstytucyjnego z dnia 17 maja 2004 r., sygn. akt SK 32/03, OTKZU nr 5/A/2004, poz. 44 Wyrok Trybunału Konstytucyjnego z dnia 4 marca 2008 r. sygn. akt SK 3/07 (Dz.U. 2008 nr 41, poz. 251) Wyrok Trybunału Konstytucyjnego z dnia 29 czerwca 2010, sygn. akt P 28/09, OTK Z. U. Nr 5A, poz. 52 Wyrok Trybunału Konstytucyjnego z dnia 25 czerwca 2012, sygn. akt K 9/10, (Dz.U. 2012, poz. 760) Wyrok Trybunału Konstytucyjnego z dnia 16 kwietnia 2015 r. sygn. akt SK 66/13, (Dz. U. z 2015 poz.560) Wyrok Sądu Najwyższego z 7 kwietnia 1999 r sygn. akt I PKN 648/98, LEX nr 37708

Wyrok Sądu Najwyższego z dnia 10 sierpnia 2000 r., sygn. akt III KKN 287/00, OSNKW 2000, nr 9-10, poz. 86

Wyrok Sądu Najwyższego z dnia 31 sierpnia 2011 r., sygn. akt II KK 99/11, LEX nr 898597 Wyrok Sądu Najwyższego z dnia 4 stycznia 2011r., sygn. akt SDI 30/10 Legalis Numer 417469 Wyrok Sądu Najwyższego z dnia 17 grudnia 2013 r., sygn. akt SDI 47/13, Legalis Numer 753859 Wyrok Sądu Najwyższego z dnia 7 lutego 2014 r., sygn. akt SDI 52/13, Legalis Numer 768704 Wyrok Sądu Najwyższego z dnia 30 października 2015 r., sygn.. akt IV KK 248/15, LEX 1818232 Wyrok Sądu Najwyższego z dnia 29 września 2015 r., sygn. akt SDI 38/15, Legalis Numer 1337383 Wyrok Sądu Najwyższego z dnia 19 marca 2015 r., sygn. akt SDI 2/15, Legalis Numer 1213097 Wyrok Sądu Najwyższego z dnia 23 września 2016 r. sygn. akt SDI 50/15, Legalis Numer 1507538 Wyrok Sądu Najwyższego z dnia 23 września 2016 r., sygn. akt SDI 31/16, Legalis Numer 1507535

\section{Streszczenie}

W artykule rozważana jest instytucja kasacji w sprawach dyscyplinarnych lekarzy. Wskazane zostały podstawowe różnice pomiędzy tą kasacją a kasacją przewidzianą przez przepisy kodeksu postępowania karnego. Ze względu na deontologię postępowania dyscyplinarnego lekarzy, nie ulega wątpliwości, że w świetle Konstytucji jest dopuszczalne i nawet nieuniknione, takie ukształtowanie modelu kontroli postępowania w przedmiocie odpowiedzialności zawodowej lekarzy, który przewiduje odstępstwa od standardów obowiązujących w postępowaniu karnym sensu stricto. Przeprowadzona w pracy analiza orzecznictwa Sądu Najwyższego w sprawach dyscyplinarnych lekarzy pod kątem efektywnej ochrony sądowej uwzględnia kasacje z lat 2011-2016.

Słowa kluczowe: kasacja, sądy lekarskie, ochrona sądowa.

\section{Judicial protection in disciplinary proceedings of doctors. Analysis of cassa- tion rulings of the Supreme Court}

\section{Summary}

This article discusses the cassation institution in disciplinary cases of doctors. The basic differences between this cassation and the cassation provided for by the Code of Criminal Procedure are indicated. Due to the deontology of the disciplinary proceedings of doctors, there is no doubt that in the light of the Constitution it is permissible and even unavoidable to form such a model of conduct control on the professional liability of physicians, which provides for derogations from the standards in force in criminal procedure sensu stricto. The analysis of Supreme Court case law in disciplinary cases of doctors in terms of effective court protection takes into account the cassations of the years 2011-2016.

Key words: cassation, medical courts, judicial protection 